\title{
Anther smuts of Silene acaulis and S. uniflora in the Outer Hebrides, including an assessment of ITS genotypes of Microbotryum silenes-acaulis
}

\author{
Paul A. Smith', Matthias Lutz², Rebekka Ziegler², and Marcin Piątek ${ }^{3}$
}

${ }^{1}$ Statistical Sciences Research Institute, University of Southampton, Highfield, Southampton, SO17 1BJ, UK; corresponding author e-mail: p.a.smith@soton.ac.uk

2Plant Evolutionary Ecology, Institute of Evolution and Ecology, University of Tübingen, Auf der Morgenstelle 5, D-72076 Tübingen, Germany ${ }^{3}$ Department of Mycology, W. Szafer Institute of Botany, Polish Academy of Sciences, Lubicz 46, PL-31-512 Kraków, Poland; corresponding author e-mail: m.piatek@botany.pl

\begin{abstract}
Anther smuts on Silene acaulis and S. uniflora from the Outer Hebrides, Scotland, UK), are analysed using morphological and molecular techniques, and found to represent Microbotryum silenes-acaulis and $M$. silenes-inflatae, respectively. This is the first identification of caryophyllaceous anther smuts in the Outer Hebrides according to modern species concepts and the first report of Microbotryum silenes-acaulis confirmed by molecular analysis from the British Isles. Additionally, the genetic structure of Microbotryum silenesacaulis, based on all currently available ITS sequences, is analysed and discussed. Seven ITS genotypes are determined for Microbotryum silenes-acaulis, including three genotypes in North America and four genotypes in Europe. Compared to European accessions, all North American accessions share specific nucleotides and are genetically divergent.
\end{abstract}

\author{
Key words: \\ arctic and alpine fungi \\ Basidiomycota \\ genotypes \\ Microbotryum \\ molecular phylogenetics \\ plant pathogens \\ Ustilaginales
}

Article info: Submitted: 19 December 2016; Accepted: 30 April 2017; Published: 11 May 2017.

\section{INTRODUCTION}

The anther smuts of Caryophyllaceae, in the past ascribed to eight species (Vánky 1994, 1998), but most commonly to Microbotryum violaceum s. lat., have recently been reassessed taxonomically. As a result, host specificity - and sometimes subtle morphological differences - has led to the division of this complex into a group of species, whose differences have been supported by DNA analyses (Freeman et al. 2002, Lutz et al. 2005, 2008, Le Gac et al. 2007, Refrégier et al. 2008, Piątek et al. 2012, 2013). Following a consolidated species concept approach (Quaedvlieg et al. 2014), anther smuts on Caryophyllaceae are currently divided into 23 species that are usually highly host-specific (Deml \& Oberwinkler 1982, 1983, Scholz \& Scholz 1988, Vánky 1988, Chlebicki \& Suková 2005, Lutz et al. 2005, 2008, Denchev 2007a, 2007b, Denchev et al. 2009, Denchev \& Denchev 2011, Piątek et al. 2012, 2013). Yet, the process of disentangling this species complex is still not finished and several groups, such as species on Dianthus (Kemler et al. 2013) or species on diverse, mostly non-European Silene species (Vánky 2012) still need to be resolved. Likewise, the geographical distribution of known species is still poorly known, not only in the non-European regions, but also in European countries.

In Great Britain and Ireland, 29 Microbotryum s. lat. (including Bauhinus and Haradaea) species (Fungal Records Database for Britian and Ireland, FRDBI; http://www. fieldmycology.net/frdbi/frdbi.asp) have been reported so far, of which 11 are anther smuts on Caryophyllaceae. The FRDBI has no records for Microbotryum species from the Outer Hebrides in Scotland, but there are published records of anther smuts under the aggregate name Ustilago violacea (s.lat.) in Campbell (1936) on Silene uniflora and Dennis (1986) on S. flos-cuculi. Recent field surveys in the Outer Hebrides have already resulted in discoveries of several smut fungi (Piątek et al. 2011, Smith \& Lutz 2013, 2014), and enlarged our knowledge of this group of plant pathogens compared to that, for example, in Dennis (1986). During fieldwork in the Outer Hebrides between 2008 and 2016, anther smuts on Silene acaulis and S. uniflora were collected. This work aims to identify the causative agents using morphological and molecular analyses and to compare them with the current state of knowledge of Microbotryum species on these hosts in Great Britain and Ireland. Additionally, the genetic structure of $M$. silenes-acaulis, based on all currently available ITS sequences, is analysed and discussed.

\section{MATERIALS AND METHODS}

\section{Specimen sampling, documentation and analysis of infection rate}

Specimens used for morphological and molecular analyses were of Microbotryum species infecting the anthers of Silene acaulis and S. uniflora, collected in 2009-2012, and preserved by pressing. Specimens used for morphological

\section{2017 International Mycological Association}

You are free to share - to copy, distribute and transmit the work, under the following conditions:

Attribution: $\quad$ You must attribute the work in the manner specified by the author or licensor (but not in any way that suggests that they endorse you or your use of the work).

Non-commercial: $\quad$ You may not use this work for commercial purposes.

No derivative works: You may not alter, transform, or build upon this work.

For any reuse or distribution, you must make clear to others the license terms of this work, which can be found at http://creativecommons.org/licenses/by-nc-nd/3.0/legalcode. Any of the above conditions can be waived if you get permission from the copyright holder. Nothing in this license impairs or restricts the author's moral rights. 
analyses only and used to summarise distributions were collected in 2008, and between 2010-2016, and also preserved by pressing. The collection details are given in Table 1. The voucher specimens are deposited in the Herbarium of the Eberhard-Karls-Universität Tübingen, Germany (TUB), and in the W. Szafer Institute of Botany, Polish Academy of Sciences, Kraków, Poland (KRAM F). In selected populations of $S$. acaulis, the numbers of infected and uninfected clumps were counted in defined areas to assess the rate of infection; only plants flowering at the time of field work could be assessed.

\section{Morphological analyses}

Morphological characters were studied using dried material. All material was analysed by light microscopy (LM). The spores were mounted in $80 \%$ lactic acid, heated to boiling point, and then examined under a Nikon Eclipse 80i light microscope (Nikon) at $\times 1000$. Spore sizes were counted using the NIS-Elements BR 3.0 imaging software (Nikon). The extreme measurements were adjusted to the nearest 0.5 $\mu \mathrm{m}$. The spore size range, mean and standard deviation of 30 spore counts from each specimen are given in Table 1. The morphological description of species includes combined values from all measured specimens. LM micrographs were taken with a Nikon DS-Fi1 camera (Nikon). The spore ornamentation of the anther smut on Silene uniflora (KRAM F-59020) was additionally analysed by scanning electron microscopy (SEM). For this purpose, dry spores were mounted on carbon tabs and fixed to an aluminium stub with double-sided transparent tape. The tabs were sputtercoated with carbon using a Cressington carbon-coater and viewed with a Hitachi S-4700 scanning electron microscope (Hitachi High-Technologies Corporation), at $10 \mathrm{kV}$ and 9,500 $\mathrm{nA}$, with a working distance of ca. $12 \mathrm{~mm}$, in the secondary electron imaging mode. SEM micrographs were taken in the Laboratory of Field Emission Scanning Electron Microscopy and Microanalysis at the Institute of Geological Sciences, Jagiellonian University, Kraków (Poland).

\section{Phylogenetic analyses}

Molecular phylogenetic analyses followed the techniques used in previous work (Piątek et al. 2013). ITS genotypes of Microbotryum silenes-acaulis were assessed using the MAFFT-alignment (available in TreeBASE: S20963) that included all ITS sequences available in GenBank (Freeman et al. 2002, Lutz et al. 2008, Hood et al. 2010) and obtained in this study. To elucidate the phylogenetic position of the Microbotryum specimens from the Outer Hebrides, their concatenated ITS + LSU sequences were analysed within the dataset of Piątek et al. (2013) that covers all caryophyllaceous anther smut species for which ITS and LSU sequences are available and comprises 21 of the 23 currently recognized species. For the final analyses, the dataset (alignment available in TreeBASE: S20963) was reduced to a maximum of two sequences per species except for the clades in which the specimens from the Outer Hebrides clustered. GenBank accession numbers of sequences generated in this study are given in Table 1.

\section{RESULTS AND DISCUSSION}

This study provides the first identification of caryophyllaceous anther smuts in the Outer Hebrides according to modern species concepts, and the first report of anther smuts on Silene acaulis in the Outer Hebrides. The anther smuts on Silene acaulis and $S$. uniflora could be assigned to two species as follows.

\section{Anther smut on Silene acaulis}

Silene acaulis is a member of the European arctic-montane element of the British flora (Preston \& Hill 1997), with only a few sites in England, Wales and Ireland, all in the higher mountains. In Scotland it is more widespread on the mountains, and also descends to sea level in a number of places. The Outer Hebrides have examples of both altitude types, with scattered plants on exposed rocky summits of a few of the higher hills in North Harris from 550-730 m, and more extensive populations in very exposed situations on the west coast of Lewis from $0-50 \mathrm{~m}$; there are also outlying populations on St Kilda and old records from Mingulay and Berneray, where it has not been found since the 1940s (Fig. 1). The pattern of $S$. acaulis genotypes in Europe and across the whole range has been investigated by Mikhaylova et al. (2010) and Gussarova et al. (2015), respectively.

Anther smut on $S$. acaulis has been found in both highaltitude and sea level populations in the Outer Hebrides, from six populations in total (Table 1, Figs 2-3). Since many of the plant records have been made by botanists who have not been looking for smuts, it is likely that many other populations have infected individuals which have not yet been recognized. The same phenomenon has been found by Hood et al. (2010), even in herbarium specimens.

The specimens in anthers of $S$. acaulis produced a violaceous, powdery spore mass replacing the pollen in pollen sacs. Spores were pale violet to violet in transmitted light, globose, subglobose, slightly ellipsoid to ovoid, 6.0-9.5(-12.0) $\times(5.5-)$ 6.0-8.0(-10.0) $\mu \mathrm{m}$ [av. \pm SD, $7.9 \pm 1.1 \times 7.1 \pm 0.7 \mu \mathrm{m}, n=$ $150 / 5]$; the wall was reticulate, ca. $0.5-1.0 \mu \mathrm{m}$ high, the meshes were more or less polyhedral, usually irregular, rarely regular, and the number of meshes per spore diameter was 4-8 (usually $6-8$ ), interspaces were smooth as observed by LM. The colour of the spore mass in the anthers, and the morphology and spore sizes of the analysed specimens agree well with those reported in the original description of Microbotryum silenes-acaulis (Lutz et al. 2008). The ITS and LSU sequences of the analysed smut specimens on $S$. acaulis from the Outer Hebrides were identical and clustered together with different accessions of anther smut on $S$. acaulis ascribed to Microbotryum silenes-acaulis (Fig. 4). Therefore, the anther smut on Silene acaulis in the Outer Hebrides is identified as $M$. silenes-acaulis.

Microbotryum silenes-acaulis is a rarely reported species in Great Britain and Ireland, with the FRDBI having only two records from Scotland (Mid-Perthshire: Ben Lawers, 1942; and North Ebudes: Isle of Skye, 1986), presumably re-annotated automatically in line with the changed nomenclature in Lutz et al. (2008). The records from Lewis are therefore a useful confirmation of the occurrence of this species, and constitute the first identification of $M$. silenes-acaulis from Great Britain and Ireland based on morphological and molecular evidence. 
Table 1. Microbotryum specimens, with host plants, spore size range, mean spore size with standard deviation, GenBank accesion numbers, and reference specimens used in this study. All sites are in vice-county 110, Outer Hebrides (Scotland).

\begin{tabular}{|c|c|c|c|c|c|}
\hline Species & Host species & Spore size range $(\mu \mathrm{m})$ & $\begin{array}{l}\text { Mean spore size } \\
\text { with standard } \\
\text { deviation }(\mu \mathrm{m})\end{array}$ & $\begin{array}{l}\text { GenBank acc. } \\
\text { no. (ITS/LSU) }\end{array}$ & Reference specimens $^{1}$ \\
\hline \multirow[t]{6}{*}{$\begin{array}{l}\text { Microbotryum } \\
\text { silenes-acaulis }\end{array}$} & Silene acaulis & $\begin{array}{l}(6.0-) 7.0-8.5(-10.0) \times \\
6.0-7.5(-8.5)\end{array}$ & $7.8 \pm 0.8 \times 6.9 \pm 0.6$ & $\begin{array}{l}\text { JN223408/ } \\
\text { JN223413 }\end{array}$ & $\begin{array}{l}\text { Loch a' Bheannaich, Lewis, NB0387 } \\
\text { 3776, } 7 \text { May 2010, P.A. Smith, TUB } \\
019585\end{array}$ \\
\hline & Silene acaulis & $\begin{array}{l}(7.0-) 7.5-9.5 \times(6.0-) \\
7.0-8.0(-8.5)\end{array}$ & $8.0 \pm 0.7 \times 7.4 \pm 0.5$ & $\begin{array}{l}\text { JN223406/ } \\
\text { JN223411 }\end{array}$ & $\begin{array}{l}\text { Mangersta sands, Lewis, NB0132 } \\
\text { 3112, } 1 \text { May 2010, P.A. Smith, TUB } \\
019586\end{array}$ \\
\hline & Silene acaulis & $\begin{array}{l}(6.0-) 7.0-9.0(-11.0) \times \\
(5.5-) 6.5-7.5(-8.0)\end{array}$ & $8.1 \pm 1.1 \times 7.0 \pm 0.6$ & $\begin{array}{l}\text { JN223407/ } \\
\text { JN223412 }\end{array}$ & $\begin{array}{l}\text { Mangersta Radio Station, Lewis, } \\
\text { NB004 331, } 4 \text { May 2010, P.A. Smith, } \\
\text { TUB } 019587\end{array}$ \\
\hline & Silene acaulis & $6.0-8.5 \times 6.0-7.5$ & $7.2 \pm 0.7 \times 6.5 \pm 0.4$ & N/A & $\begin{array}{l}\text { Druim a' Bheannaich, Lewis, NB0338, } \\
7 \text { May } 2010 \text {, leg. P.A. Smith, KRAM } \\
\text { F-59018 }\end{array}$ \\
\hline & Silene acaulis & $\begin{array}{l}6.5-11.5(-12.0) \times \\
6.0-9.0(-10.0)\end{array}$ & $8.3 \pm 1.5 \times 7.5 \pm 0.9$ & $\mathrm{~N} / \mathrm{A}$ & $\begin{array}{l}\text { Ceartabhal, summit, N. Harris, } 550 \text { m, } \\
\text { NB043127, } 17 \text { June 2013, P.A. Smith, } \\
\text { KRAM F-59019 }\end{array}$ \\
\hline & Silene acaulis & No specimen available & $\begin{array}{l}\text { No specimen } \\
\text { available }\end{array}$ & $\begin{array}{l}\text { No specimen } \\
\text { available }\end{array}$ & $\begin{array}{l}\text { Camas Geodhachan an Duilisg, Aird } \\
\text { Uig, Lewis, } 20 \text { m, NB0448 3845, } 29 \\
\text { April 2010, P.A. Smith, not preserved }\end{array}$ \\
\hline \multirow[t]{12}{*}{$\begin{array}{l}\text { Microbotryum } \\
\text { silenes-inflatae }\end{array}$} & Silene uniflora & $\begin{array}{l}(5.5-) 7.0-8.5 \times(5.5-) \\
6.5-8.0\end{array}$ & $7.7 \pm 0.7 \times 7.0 \pm 0.6$ & $\begin{array}{l}\text { JN223404/ } \\
\text { JN223409 }\end{array}$ & $\begin{array}{l}\text { Sgiogarstaigh, Lewis, NB56L, } 31 \text { July } \\
\text { 2009, P.A. Smith, TUB } 019589\end{array}$ \\
\hline & Silene uniflora & $\begin{array}{l}7.0-9.0(-11.0) \times(6.0-) \\
7.0-8.5(-10.0)\end{array}$ & $8.5 \pm 0.9 \times 7.7 \pm 0.8$ & $\begin{array}{l}\text { JN223405/ } \\
\text { JN223410 }\end{array}$ & $\begin{array}{l}\text { Leum Langa, Lewis, NB560572, } 6 \\
\text { Aug. 2009, P.A. Smith, TUB } 019588\end{array}$ \\
\hline & Silene uniflora & $\begin{array}{l}(6.0-) 6.5-8.5 \times(5.5-) \\
6.0-7.5\end{array}$ & $7.2 \pm 0.7 \times 6.7 \pm 0.5$ & $\begin{array}{l}\text { KY321304/ } \\
\text { KY321305 }\end{array}$ & $\begin{array}{l}\text { Gasgeir, NA8711, } 13 \text { July 2012, M. } \\
\text { Inglis, KRAM F-59020 }\end{array}$ \\
\hline & Silene uniflora & $6.5-9.0 \times(6.0-) 6.5-8.5$ & $7.4 \pm 0.9 \times 6.9 \pm 0.7$ & $\mathrm{~N} / \mathrm{A}$ & $\begin{array}{l}\text { Pabaigh Mor, Lewis, NB13E, } 30 \text { June } \\
\text { 2008, P.A. Smith, KRAM F-59021 }\end{array}$ \\
\hline & Silene uniflora & $6.5-9.5 \times 6.5-8.5(-9.0)$ & $7.7 \pm 0.8 \times 7.4 \pm 0.7$ & $\mathrm{~N} / \mathrm{A}$ & $\begin{array}{l}\text { Lingail Mor, Uig, Lewis, NB027345, } \\
1 \text { July } 2008, \text { P.A. Smith, KRAM } \\
\text { F-59022 }\end{array}$ \\
\hline & Silene uniflora & $6.0-7.5 \times(5.5-) 6.0-7.0$ & $6.7 \pm 0.5 \times 6.4 \pm 0.4$ & N/A & $\begin{array}{l}\text { Bearasaigh, Loch Roag, Lewis, } \\
\text { NB14G, } 3 \text { July 2008, P.A. Smith, } \\
\text { KRAM F-59023 }\end{array}$ \\
\hline & Silene uniflora & $6.5-9.5 \times 6.0-8.5$ & $7.5 \pm 0.9 \times 6.9 \pm 0.7$ & N/A & $\begin{array}{l}\text { Flodaigh, Loch Roag, Lewis, NB14F, } \\
3 \text { July } 2008, . \text { P.A. Smith, KRAM } \\
\text { F-59024 }\end{array}$ \\
\hline & Silene uniflora & $(6.0-) 6.5-8.0 \times 6.0-7.5$ & $7.1 \pm 0.6 \times 6.7 \pm 0.4$ & $\mathrm{~N} / \mathrm{A}$ & $\begin{array}{l}\text { Seana Cnoc, Loch Roag, Lewis, } \\
\text { NB14B, } 3 \text { July 2008,. P.A. Smith, } \\
\text { KRAM F-59025 }\end{array}$ \\
\hline & Silene uniflora & $\begin{array}{l}6.5-8.0 \times(5.5-) 6.0- \\
7.5(-8.0)\end{array}$ & $7.1 \pm 0.6 \times 6.7 \pm 0.6$ & $\mathrm{~N} / \mathrm{A}$ & $\begin{array}{l}\text { Knoch Ibidale, sea cliff, Lewis, } \\
\text { NB5413 3161, } 24 \text { April 2014, P.A. } \\
\text { Smith, KRAM F-59026 }\end{array}$ \\
\hline & Silene uniflora & $6.5-8.5 \times 6.5-7.5(-8.5)$ & $7.6 \pm 0.6 \times 7.0 \pm 0.5$ & $\mathrm{~N} / \mathrm{A}$ & $\begin{array}{l}\text { Loch Eirearaigh, shingle bank, Lewis, } \\
\text { NB32783 50700, } 30 \text { July 2016, P.A. } \\
\text { Smith, KRAM F-59027 }\end{array}$ \\
\hline & Silene uniflora & $\begin{array}{l}(6.5-) 7.0-8.5(-10.0) \times \\
6.5-8.0(-9.5)\end{array}$ & $7.9 \pm 0.9 \times 7.4 \pm 0.7$ & $\mathrm{~N} / \mathrm{A}$ & $\begin{array}{l}\text { Aird Bheag Bhragair, cliff, Lewis, } \\
\text { NB27833 49633, } 3 \text { August 2016, P.A. } \\
\text { Smith, KRAM F-59028 }\end{array}$ \\
\hline & Silene uniflora & $\begin{array}{l}(5.5-) 6.5-7.5(-8.5) \times \\
(5.5-) 6.0-7.0(-8.0)\end{array}$ & $7.1 \pm 0.7 \times 6.7 \pm 0.5$ & $\mathrm{~N} / \mathrm{A}$ & $\begin{array}{l}\text { Liongam, by loch, NA996 197, } 11 \\
\text { August } 2016, \text { P.A. Smith, KRAM } \\
\text { F-59029 }\end{array}$ \\
\hline
\end{tabular}

${ }^{1}$ KRAM F, Mycological Collections, W. Szafer Institute of Botany, Polish Academy of Sciences, Kraków, Poland; TUB, Eberhard-Karls-Universität Tübingen, Germany.

\section{Infection rates}

Bueker et al. (2016) discussed the correlation between isolation in populations and the incidence of infection by Microbotryum silenes-acaulis. They found that the incidence of infection was greater in more northern latitudes and in 


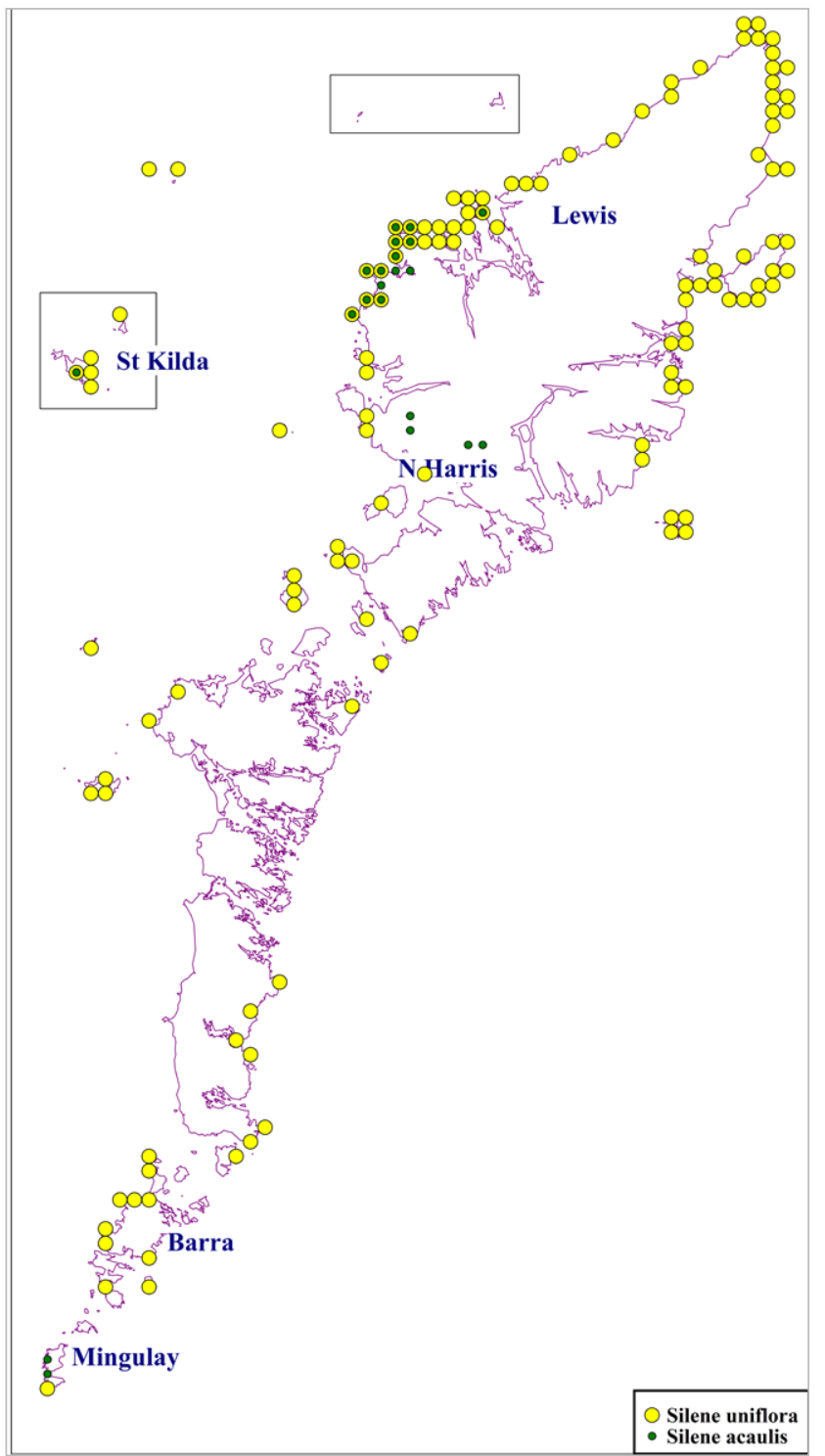

Fig. 1. Distributions of Silene acaulis and S. uniflora in the Outer Hebrides based on all records from any date. Localities mentioned in the text are named.

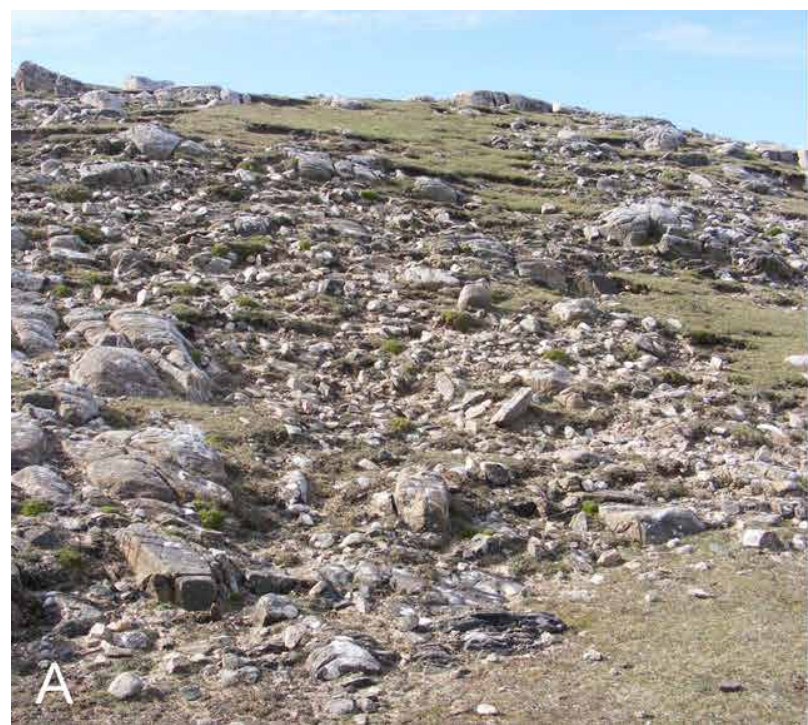

be relatively high, and infection rates within populations in 2010 were estimated at $9 \%$ at Loch a' Bheannaich, $4 \%$ at Mangersta Sands, and $25 \%$ at Mangersta Radio Station (see Table 1 for locality details). These are all higher than the average $2.9 \%$ found by Bueker et al. (2016) across the known distribution range based on herbarium specimens, although the populations represented by these specimens will have varying infection rates, some higher and some lower than the average. The population infection rate is likely to be much higher, as to date all populations which have been searched specifically for infections have been found to contain infected individuals.

Abbate \& Antonovics (2014) investigated a related hostpathogen system with Microbotryum species and Silene vulgaris. They found that "disease was more likely to be found where overall temperatures were lower, fluctuations in diurnal and seasonal temperatures were smaller, and where precipitation totals were greater and more stable". This succinctly describes conditions in the Outer Hebrides, which have mild winters and cool summers because of their extreme oceanicity, and one of the smallest annual temperature ranges in Britain $\left(8.8^{\circ} \mathrm{C}\right.$ in Stornoway). More information on climate in the Outer Hebrides is provided by Angus (1997: 178-200). The high infection rates observed are therefore consistent with both isolation and climate.

\section{Genetic diversity}

The ITS sequences of Microbotryum silenes-acaulis from different geographic areas differed. Based on all ITS sequences available in GenBank (Freeman et al. 2002, Lutz et al. 2008, Hood et al. 2010) and those obtained in this study, and assuming that there were no sequencing errors, seven ITS genotypes were determined for $M$. silenes-acaulis (Figs 4-5). First, these genotypes reveal a disjunction between $M$. silenes-acaulis specimens from North America and from Europe. Compared to European accessions, all North American accessions share specific nucleotides and differ genetically. This is congruent with the genetic structure of the host plant Silene acaulis. North American populations are genetically distinct from other world populations (from Europe and Siberia) having nine unique plastid DNA haplotypes of the 17 haplotypes detected across

Fig. 2. Microbotryum silenes-acaulis on Silene acaulis. A. The habitat at Loch a' Bheannaich, Lewis. B. Infected and uninfected flowers at the same locality. Note that this is a female tussock, but the fungus has induced infected flowers to produce stamens. (Corresponds to TUB 019585; scale bar approx $1 \mathrm{~cm})$.

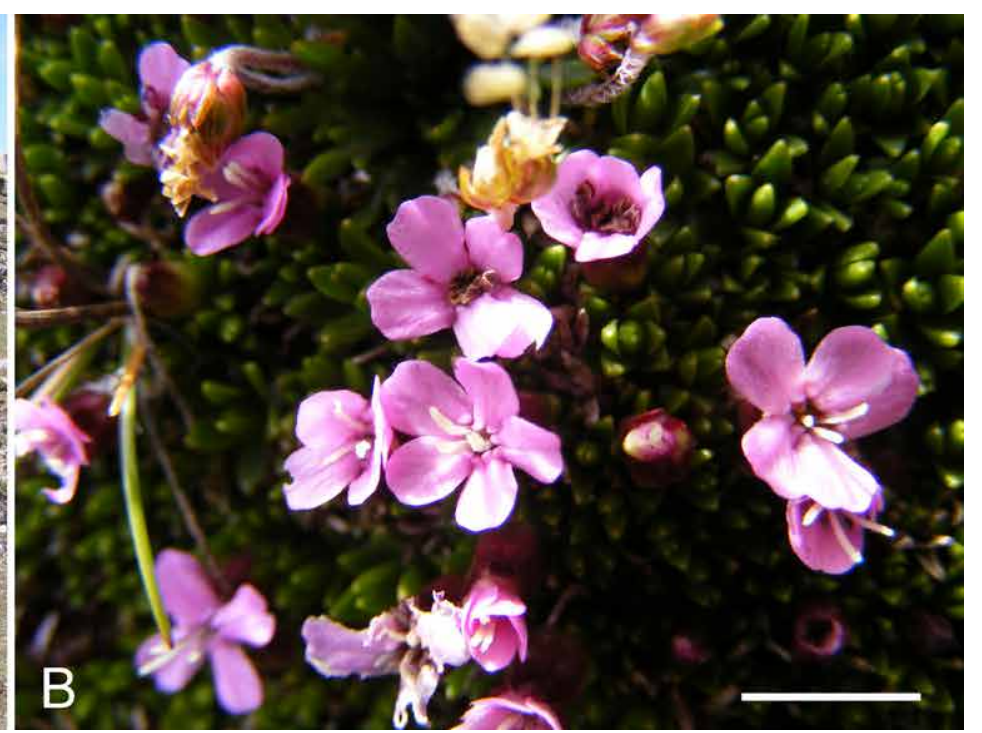




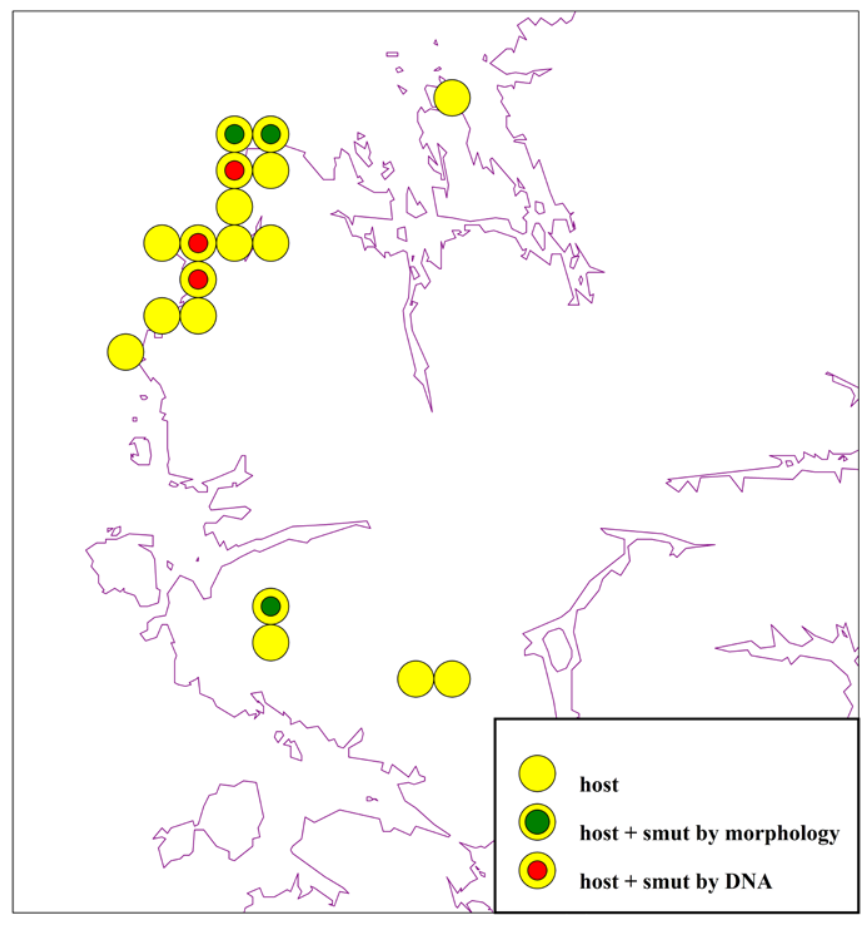

Fig. 3. Distribution of Microbotryum silenes-acaulis on Silene acaulis in the Outer Hebrides.

the whole geographical range of the species (Gussarova et al. 2015). Future studies including a larger sampling and infection trials should reveal whether specific nucleotides and the genetic divergence between North American and European accessions of $M$. silenes-acaulis indicate that the anther smuts on $S$. acaulis in these areas belong to two distinct species. Recent studies of different fungi revealed that morphologically similar species in North America and Europe, earlier unified under the same specific epithet, are divergent genetically and represent distinct species (e.g. Hughes et al. 2014, Spirin et al. 2015, 2016).

The European accessions of $M$. silenes-acaulis show a phylogenetic substructure that separates specimens from Austria (Eastern Alps) and Italy (Central Apennines), ones from Poland (Tatra Mts), and those from Switzerland (western part of the Eastern Alps), Sweden (Lapland), and the Outer Hebrides (Fig. 4). The sequences from the Outer Hebrides specimens differ in one nucleotide position from sequences obtained from Swedish and Swiss specimens (Fig. 5). The existence of a distinct genotype of $M$. silenes-acaulis in the Tatra Mts is noteworthy and may indicate a long period of isolation of the anther smut population in this mountain range. Previous studies detected the occurrence of distinct genotypes of the alpine vascular plants Carex atrofusca (Schönswetter et al. 2006) and Ranunculus glacialis (Ronikier et al. 2012) in the Tatra Mts, but our new work is the first indication of the occurrence of distinct genotypes amongst representatives of Fungi. More intensive sampling of ITS sequences (and maybe other markers) from other mountain and arctic populations of $M$. silenes-acaulis is needed; this may confirm or modify the currently inferred phylogenetic structure within this species.

Bueker et al. (2016) have recently analysed the genetic pattern of $M$. silenes-acaulis across its range using microsatellite markers derived from herbarium specimens. There are clear patterns with reduced diversity in northern latitudes. Bueker et al. (2016) did not include any specimens from Great Britain, Ireland or the Tatra Mts, and their genetic analyses were based on microsatellites rather than ITS, so it is not clear how the Outer Hebrides or the Tatra specimens would fit into this structure. Nevertheless, the residual structure in the phylogenetic hypothesis for $M$. silenesacaulis (Fig. 4) agrees with Bueker et al. (2016)'s pattern, with distinctions between North America and Europe, and within Europe between northern and southern latitudes. The grouping of the Outer Hebrides specimens with those from Sweden and Switzerland is also consistent with Bueker et al. (2016)'s groups, which show some genotypes in common between Scandinavia and the Alps. The homology of these groupings, however, remains to be demonstrated.

\section{Anther smut on Silene uniflora}

Silene uniflora is a common, gynodioecious, coastal plant in Great Britain and Ireland, but also has some inland populations, usually at higher altitudes in mountains or in heavy metal contaminated sites (Marsden-Jones \& Turrill 1957), giving a distribution which is qualitatively similar to that of $S$. acaulis, though it is a much more frequent species (Preston et al. 2002: 176). Silene uniflora is closely related to S. vulgaris, which is also widely distributed in Great Britain and Ireland, but has a generally more southern distribution and is often found inland. Two species of anther smut, Microbotryum silenes-inflatae and M. lagerheimii, have been reported as infecting Silene uniflora from south-west England by Chung et al. (2012), who report sympatric populations of these two Microbotryum species in Somerset and Suffolk (SW and SE England, respectively).

In the Outer Hebrides, Silene uniflora is the only one of the $S$. uniflora/S. vulgaris species pair so far known, and it is exclusively coastal, usually growing on shingle banks, rocks and cliffs where it is protected from grazing (Fig. 1). Smutted flowers are occasional, and were first reported in the Outer Hebrides from Barra by Campbell (1936). Fieldwork since 2008 has identified smutted flowers from 12 locations (Table 1, Fig. 6), and these specimens have been analysed in more detail below. In the same way as for $S$. acaulis, smutted flowers are almost certainly much more frequent than has been recorded, as plant records are generally made by people who are not looking out for smuts.

The specimens in anthers of $S$. uniflora produced a relatively dark violaceous, occasionally light violaceous (one specimen: from Gasgeir, KRAM F-59020), powdery spore mass replacing the pollen in pollen sacs. Spores were pale violet in transmitted light, globose, subglobose, slightly ellipsoid to ovoid, (5.5-)6.5-9.5(-11.0) $\times$ (5.5-)6.0-8.5(10.0) $\mu \mathrm{m}$ [av. $\pm \mathrm{SD}, 7.5 \pm 0.9 \times 6.9 \pm 0.7 \mu \mathrm{m}, n=360 / 12$ ]; the wall was reticulate, ca. $1.0 \mu \mathrm{m}$ high, the meshes were more or less polyhedral, usually irregular, rarely regular, and the number of meshes per spore diameter was 5-9 (usually 6 ), interspaces were smooth as observed by LM, smooth or rugulose as observed by SEM (Fig. 7). The colour of the spore mass in the anthers, and the morphology and spore sizes of the analysed specimens agree well with those reported in the description of $M$. silenes-inflatae (Denchev 


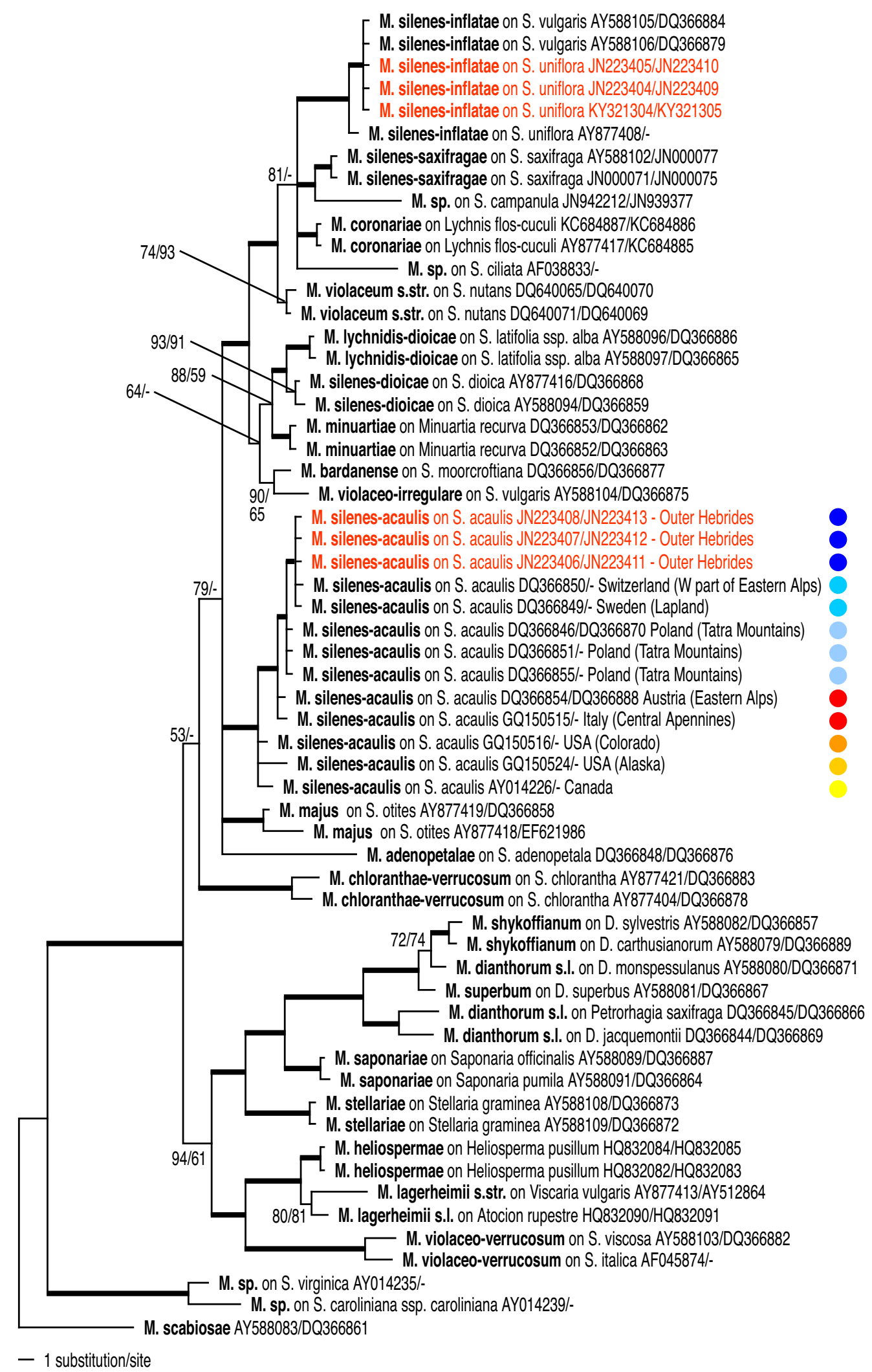

Fig. 4. Bayesian inference of phylogenetic relationships between the sampled Microbotryum species: Markov chain Monte Carlo analysis of an alignment of concatenated ITS + LSU base sequences using the GTR+I+G model of DNA substitution with gamma distributed substitution rates and estimation of invariant sites, random starting trees, and default starting parameters of the DNA substitution model. A $50 \%$ majority-rule consensus tree is shown computed from 75000 trees that were sampled after the process had reached stationarity. The topology was rooted with Microbotryum scabiosae. Numbers on branches before slashes are estimates for a posteriori probabilities; numbers on branches after slashes are ML bootstrap support values. Branch lengths were averaged over the sampled trees. They are scaled in terms of expected numbers of nucleotide substitutions per site. The colour dots refer to ITS genotypes of Microbotryum silenes-acaulis (see also Fig. 5). D. = Dianthus, M. = Microbotryum, S. = Silene. 


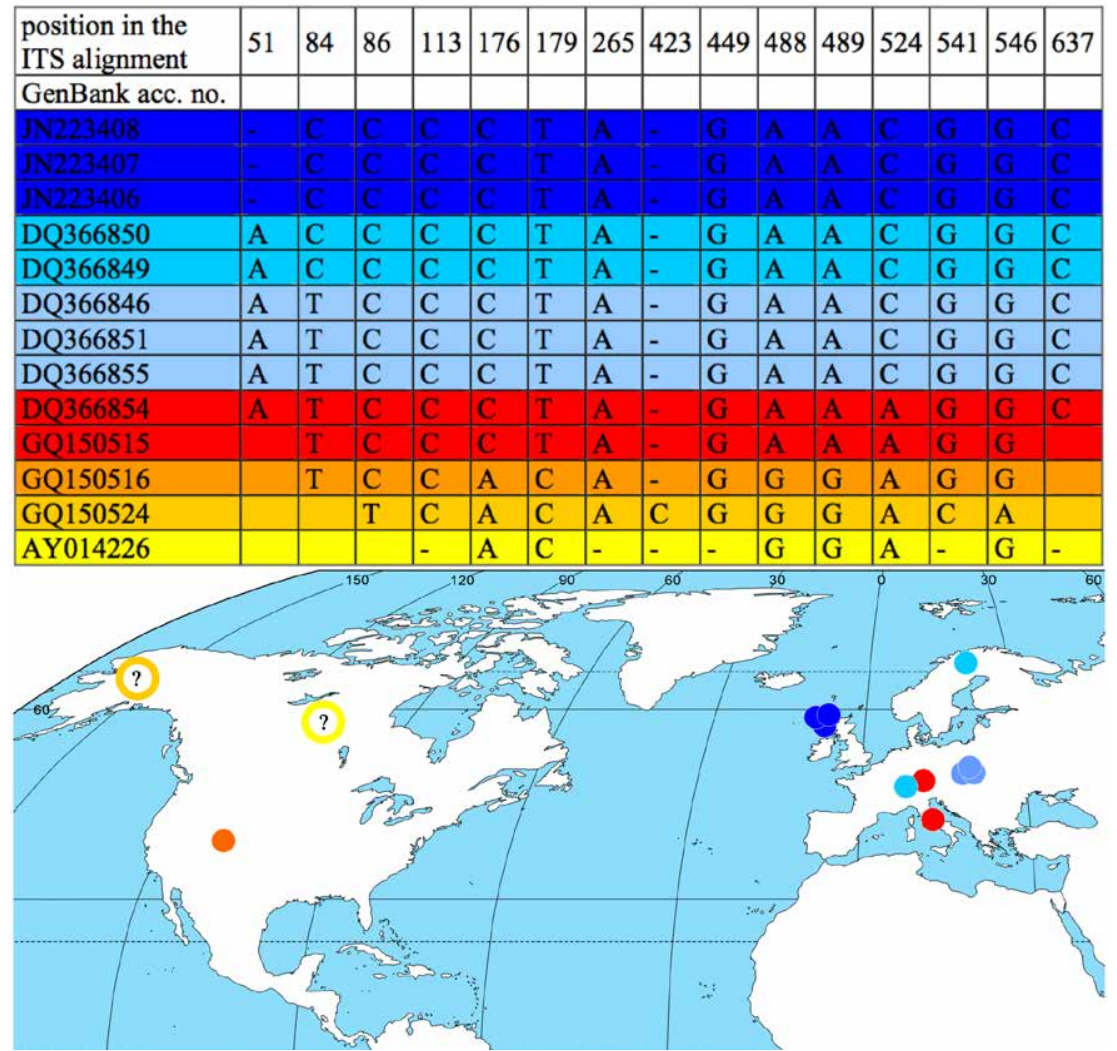

Fig. 5. Nucleotide differences between aligned ITS sequences, and the geographical distribution of corresponding specimens of Microbotryum silenesacaulis. Locations depicted with a question mark are not precise as they were included in GenBank as Alaska and Canada, respectively. Colours refer to ITS genotypes (see also Fig. 4).

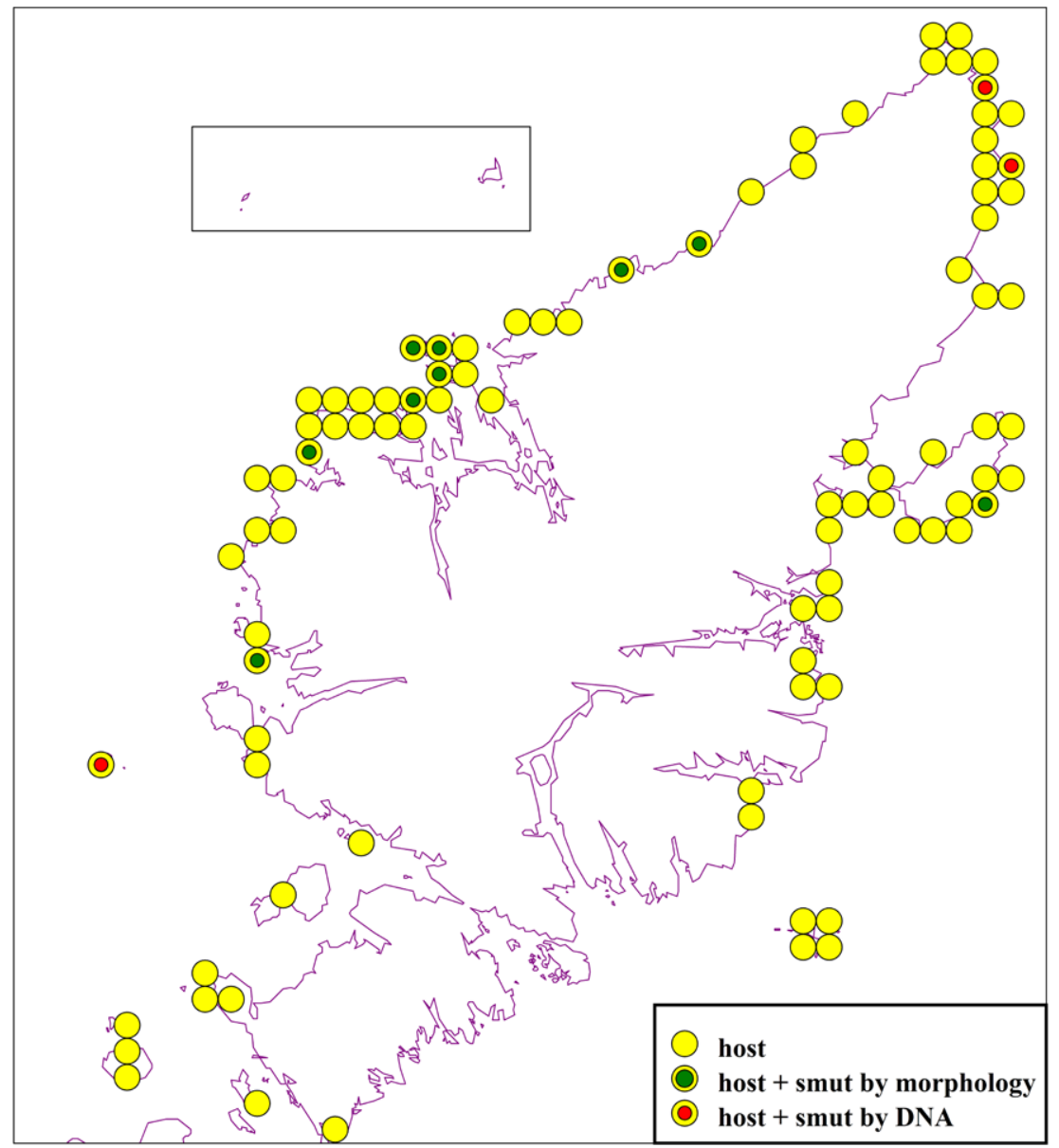

Fig. 6. Records of Microbotryum silenesinflatae on Silene uniflora from the Outer Hebrides since 2008.

2007b). Based on the relatively dark violaceous spore mass from specimens in locations where ITS and LSU sequences were not investigated, all of the remaining collected smuts on S. uniflora were assigned to $M$. silenes-inflatae. The colour

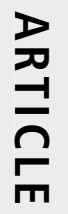



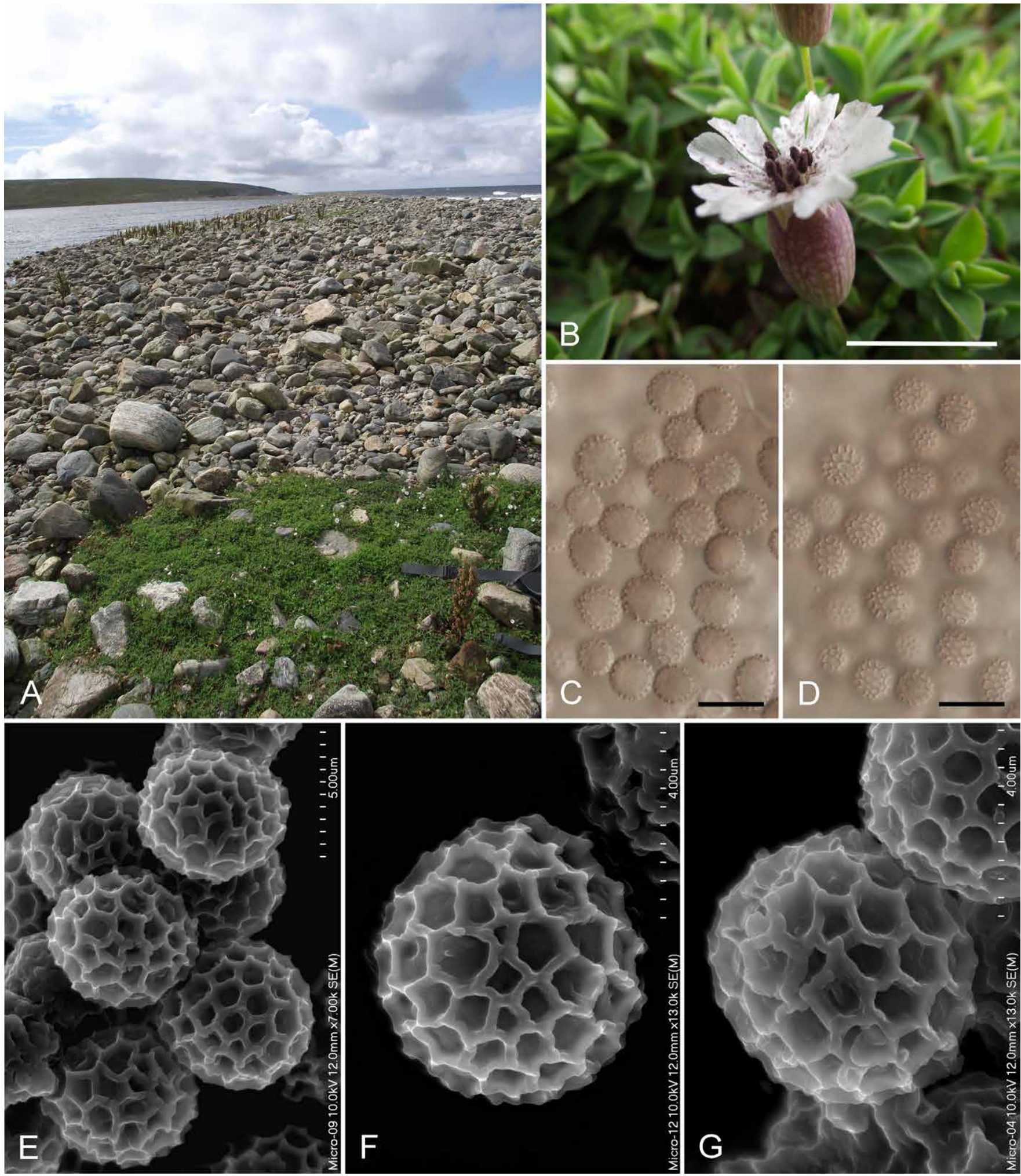

Fig. 7. Microbotryum silenes-inflatae on Silene uniflora from the Outer Hebrides. A. The habitat at Loch Eirearaigh, Lewis. B. Infected flower at the same locality (corresponds to KRAM F-59027; scale bar approx $1 \mathrm{~cm}$ ). C-D. Spores seen by LM, median and superficial views (TUB 019588). E-F. Spores seen by SEM (KRAM F-59020). Bars: C-D $=10 \mu \mathrm{m}, \mathrm{E}=5 \mu \mathrm{m}, \mathrm{F}-\mathrm{G}=4 \mu \mathrm{m}$.

from $S$. uniflora is shown here for the first time, and is roughly congruent with those published for specimens of $M$. silenesinflatae on S. vulgaris (Deml \& Oberwinkler 1983, Vánky 1985, 1994).

The ITS and LSU sequences of the three smut specimens on S. uniflora analysed from the Outer Hebrides, including the specimen from Gasgeir (KRAM F-59020) with light violaceous sori, were identical and clustered together with the anther smut specimens on $S$. vulgaris from Austria and Switzerland (ITS/LSU: AY588105/DQ366884, AY588106/ DQ366879; Lutz et al. 2008). The ITS sequence of the smut specimen on S. uniflora from Norway (AY877408; Lutz et al. 
2005) differed in $3 \mathrm{bp}(0.48 \%)$. All these specimens were assigned to $M$. silenes-inflatae (Fig. 4). Therefore, the anther smut on $S$. uniflora in the Outer Hebrides is identified as that species.

Microbotryum silenes-inflatae is already known from Great Britain and Ireland, with more than 40 records in FRDBI on $S$. uniflora and $S$. vulgaris assigned to this species, mostly on the basis of host plant information. It is likely that other collections of anther smuts on this group of hosts, tentatively assigned in FRDBI to Microbotryum sp. or M. violaceum, will prove to be the same species. Caution is necessary, however, as some of these records may represent $M$. lagerheimii, which could also infect $S$. uniflora and $S$. vulgaris (Denchev 2007b, Chung et al. 2012). Most records are from England and Wales, with a few records from Scotland, the Channel Islands, and Ireland. In addition to the reports of $M$. silenes-inflatae on Silene uniflora from south-west England (Chung et al. 2012) based on a molecular identification, our study provides the first reports of this species from the Outer Hebrides (Scotland) supported by both morphological and molecular identifications. Both studies provide reliable, DNAbased, evidence for the occurrence of this fungus in Great Britain and Ireland.

\section{ACKNOWLEDGEMENTS}

We thank Anna Łatkiewicz (Kraków) for technical help with scanning electron microscopy. Marcin Piątek was supported by the statutory funds of the W. Szafer Institute of Botany, Polish Academy of Sciences, Kraków, Poland.

\section{REFERENCES}

Abbate JL, Antonovics J (2014) Elevational disease distribution in a natural plant-pathogen system: insights from changes across host populations and climate. Oikos 123: 1126-1136.

Angus S (1997) The Outer Hebrides: the shaping of the islands. Cambridge: White Horse Press.

Bueker B, Eberlein C, Gladieux P, Schaefer A, Snirc A, et al. (2016) Distribution and population structure of the anther smut fungus Microbotryum silenes-acaulis parasitizing an arctic-alpine plant. Molecular Ecology 25: 811-824.

Campbell ME (1936) The natural history of Barra, Outer Hebrides: fungi. Proceedings of the Royal Physical Society of Edinburgh 22: 259-260.

Chlebicki A, Suková M (2005) Two Microbotryum species from the Himalayas. Mycotaxon 93: 149-154.

Chung E, Petit E, Antonovics J, Pedersen AB, Hood ME (2012) Variation in resistance to multiple pathogen species: anther smuts of Silene uniflora. Ecology and Evolution 2: 2304-2314.

Deml G, Oberwinkler F (1982) Studies in Heterobasidiomycetes, Part 24. On Ustilago violacea (Pers.) Rouss. from Saponaria officinalis L. Phytopathologische Zeitschrift 104: 345-356.

Deml G, Oberwinkler F (1983) Studies in Heterobasidiomycetes, Part 31. On the anther smuts of Silene vulgaris (Moench) Garcke. Phytopathologische Zeitschrift 108: 61-70.

Denchev CM (2007a) Microbotryum savilei sp. nov. (Microbotryaceae). Mycologia Balcanica 4: 69-73.
Denchev CM (2007b) Microbotryum lagerheimii sp. nov. (Microbotryaceae). Mycologia Balcanica 4: 61-67.

Denchev CM, Giraud T, Hood ME (2009) Three new species of anthericolous smut fungi on Caryophyllaceae. Mycologia Balcanica 6: 79-84.

Denchev CM, Denchev TT (2011) New records of smut fungi. 4. Microbotryum coronariae comb. nov. Mycotaxon 118: 53-56.

Dennis RWG (1986) Fungi of the Hebrides. Kew: Royal Botanic Gardens.

Freeman AB, Doung KK, Shi T, Hughes CF, Perlin MH (2002) Isolates of Microbotryum violaceum from North American host species are phylogenetically distinct from their European hostderived counterparts. Molecular Phylogenetics and Evolution 23 158-170.

Gussarova G, Allen GA, Mikhaylova Y, McCormick LJ, Mirré V, et al. (2015) Vicariance, long-distance dispersal, and regional extinction-recolonization dynamics explain the disjunct circumpolar distribution of the arctic-alpine plant Silene acaulis. American Journal of Botany 102: 1703-1720.

Hood ME, Mena-Alí JI, Gibson AK, Oxelman B, Giraud T, et al. (2010) Distribution of the anther-smut pathogen Microbotryum on species of the Caryophyllaceae. New Phytologist 187: 217-229.

Hughes KW, Segovia AR, Petersen RH (2014) Transatlantic disjunction in fleshy fungi. I. The Sparassis crispa complex. Mycological Progress 13: 407-427.

Kemler M, Martín MP, Telleria MT, Schäfer AM, Yurkov A, Begerow D (2013) Contrasting phylogenetic patterns of anther smuts (Pucciniomycotina: Microbotryum) reflect phylogenetic patterns of their caryophyllaceous hosts. Organisms, Diversity and Evolution 13: 111-126.

Le Gac M, Hood ME, Fournier E, Giraud T (2007) Phylogenetic evidence of host-specific cryptic species in the anther smut fungus. Evolution 61: 15-26.

Lutz M, Bauer R, Begerow D, Oberwinkler F, Triebel D (2004) Tuberculina, rust relatives attack rusts. Mycologia 96: 614-626.

Lutz M, Göker M, Piątek M, Kemler M, Begerow D, Oberwinkler F (2005) Anther smuts of Caryophyllaceae: molecular characters indicate host-dependent species delimitation. Mycological Progress 4: 225-238.

Lutz M, Piątek M, Kemler M, Chlebicki A, Oberwinkler F (2008) Anther smuts of Caryophyllaceae: molecular analyses reveal further new species. Mycological Research 112: 1280-1296.

Marsden-Jones E, Turrill WB (1957) The Bladder Campions (Silene maritima and S. vulgaris). London: Ray Society.

Mikhaylova YV, Gussarova GL, Brochmann C (2010) Molecular variation and phylogeography of the moss campion Silene acaulis (L.) Jacq. (Caryophyllaceae) in the North of Europe and the Svalbard archipelago. Ecological Genetics 8: 52-60 (in Russian).

Piątek M, Lutz M, Smith PA, Chater AO (2011) A new species of Antherospora supports the systematic placement of its host plant. IMA Fungus 2: 135-142.

Piątek M, Lutz M, Ronikier A, Kemler M, Świderska-Burek U (2012) Microbotryum heliospermae, a new anther smut fungus parasitic on Heliosperma pusillum in the mountains of the European Alpine System. Fungal Biology 116: 185-195.

Piątek M, Lutz M, Kemler M (2013) Microbotryum silenes-saxifragae sp. nov. sporulating in the anthers of Silene saxifraga in southern European mountains. IMA Fungus 4: 29-40.

Preston CD, Hill MO (1997) The geographical relationships of British 
and Irish vascular plants. Botanical Journal of the Linnean Society 124: 1-120.

Preston CD, Pearman DA, Dines TD (2002) New Atlas of the British and Irish Flora: an atlas of the vascular plants of Britain, Ireland, the Isle of Man and the Channel Islands. Oxford: Oxford University Press.

Quaedvlieg W, Binder M, Groenewald JZ, Summerell BA, Carnegie AJ, et al. (2014) Introducing the consolidated species concept to resolve species in the Teratosphaeriaceae. Persoonia 33: 1-40.

Refrégier G, Le Gac M, Jabbour F, Widmer A, Shykoff JA, et al. (2008) Cophylogeny of the anther smut fungi and their caryophyllaceous hosts: prevalence of host shifts and importance of delimiting parasite species for inferring cospeciation. BMC Evolutionary Biology 8: 100.

Ronikier M, Schneeweiss GM, Schönswetter P (2012) The extreme disjunction between Beringia and Europe in Ranunculus glacialis s. I. (Ranunculaceae) does not coincide with the deepest genetic split - a story of the importance of temperate mountain ranges in arctic-alpine phylogeography. Molecular Ecology 21: 5561-5578.

Scholz H, Scholz I (1988) Die Brandpilze Deutschlands (Ustilaginales). Englera 8: 1-691.

Schönswetter P, Popp M, Brochmann C (2006) Central Asian origin of and strong genetic differentiation among populations of the rare and disjunct Carex atrofusca (Cyperaceae) in the Alps. Journal of Biogeography 33: 948-956.
Smith PA, Lutz M (2013) The rare smut fungus Urocystis fischeri (Urocystidales, Ustilaginomycotina) from the Outer Hebrides, Scotland, with notes on its systematic position. Glasgow Naturalist 26: 112-114.

Smith PA, Lutz M (2014) Ustilentyloma fluitans - a new British smut. Field Mycology 15: 8.

Spirin V, Runnel K, Vlasák J, Miettinen O, Põldmaa K (2015) Species diversity in the Antrodia crassa group (Polyporales, Basidiomycota). Fungal Biology 119: 1291-1310.

Spirin V, Vlasák J, Rivoire B, Kotiranta H, Miettinen O (2016) Hidden diversity in the Antrodia malicola group (Polyporales, Basidiomycota). Mycological Progress 15: 51.

Vánky K (1985) Carpathian Ustilaginales. Symbolae Botanicae Upsalienses 24(2): 1-309.

Vánky K (1988) Taxonomical studies on Ustilaginales. III. Mycotaxon 33: 365-374.

Vánky K (1994) European Smut Fungi. Stuttgart: G. Fischer Verlag. Vánky K (1998) The genus Microbotryum (smut fungi). Mycotaxon 67: 33-60.

Vánky K (2012) Smut Fungi of the World. St Paul, MN: American Phytopathological Society Press. 